\title{
The Academic Community and its Role in Environmental (Air) Licensing ${ }^{1}$
}

\author{
La comunidad académica y su rol en el licenciamiento ambiental
}

\author{
Barron Henderson (1) \\ (1) PhD Environmental Science and Engineering, University of North Carolina. Post-doctoral Research Fellow, U.S. Environmental Protec- \\ tion Agency (EPA). Assistant Professor in Environmental Engineering Sciences at the University of Florida, United States. \\ barronh@ufl.edu
}

Received October 26th, 2015. Modified December 10th, 2015. Approved December 15th, 2015.

DOI: http//:dx.doi.org/10.16924/riua.v0i43.899

\section{Key words}

Academic Community, Environmental Licensing, Environmental Protection Agency, Regulations, United States.

\section{Abstract}

Environmental licensing plays a critical role in protecting human health, the environment, and the earth's climate. Licensing works best when regulators, the private sector, and academics work together. Working together, however, can be difficult when the levels of trust between the parties are limited. Research engineers and scientists can strengthen trust when they provide unbiased research. The United States (US) Environmental Protection Agency's (EPA) licensing process establishes clear roles for the research community and, often, clear requirements, which help build trust in the licensing process. This article will describe key feature of the US regulatory process that strengthen stakeholder trust, and provide anecdotes from recent experiences.

\section{Palabras clave}

Agencia de Protección Ambiental, comunidad académica, Estados Unidos, licenciamiento ambiental, regulaciones.

\section{Resumen}

El licenciamiento ambiental juega un papel fundamental en la protección de la salud, el medio ambiente y el clima. Este proceso funciona mejor cuando los reguladores, el sector privado y los académicos trabajan juntos. Para ello, es necesaria la confianza entre todas las partes. La Agencia de Protección Ambiental de Estados Unidos (EPA) tiene funciones y requisitos claros para la comunidad científica. Esto ayuda a fortalecer la confianza en el proceso de concesión de licencias. Además, investigadores y científicos pueden fortalecer esa confianza proporcionando investigación imparcial. Este artículo describirá las características del proceso regulatorio de Estados Unidos y mostrará anécdotas de experiencias recientes.

\section{United States Regulatory Process}

No environmental licensing process is perfect, but we can learn a lot from each of them. As an air pollution scientist, my experience is primarily within the context of air in the US. The primary authority for air related licensing in the US comes from the Clean Air Act (CAA). Figure 1 shows that the CAA was drafted by US Congress and ultimately approved by US president Lyndon B. Johnson in 1963. The CAA was subsequently extended and strengthened under Richard Nixon, and amended by Congress under Jimmy Carter and George H. W. Bush. The 1970 Amendments to the CAA gave the EPA the authority to make regulations and work with states to monitor and enforce regulatory compliance.

The EPA's regulatory authority is a big responsibility. The EPA's mandate as an agency is to develop regulations that protect human health and welfare within an adequate margin of safety. That means identifying risks, understanding their uncertainties, and making rules that minimize that risk. To achieve their goal, the EPA must rely on the broader scientific community, which includes scientists and engineers that focus on issues ranging from human cell response to toxins, to the effectiveness of new catalyst materials

1 This article is based on a lecture by Barron Henderson presented in the forum “The Role of Engineering and Engineering Science in Environmental Licensing” held at Universidad de los Andes on October 26th, 2015. 

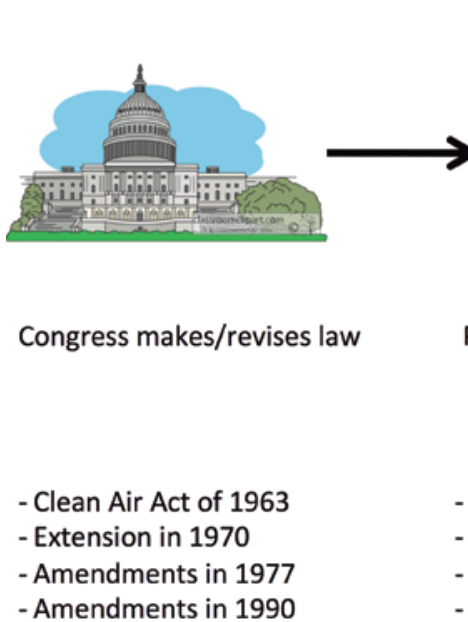

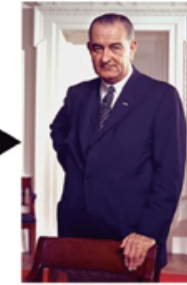

President approves



Agency develops, monitors and enforces regulations
- Lyndon B. Johnson

- Richard Nixon

- Jimmy Carter

- George H. W. Bush
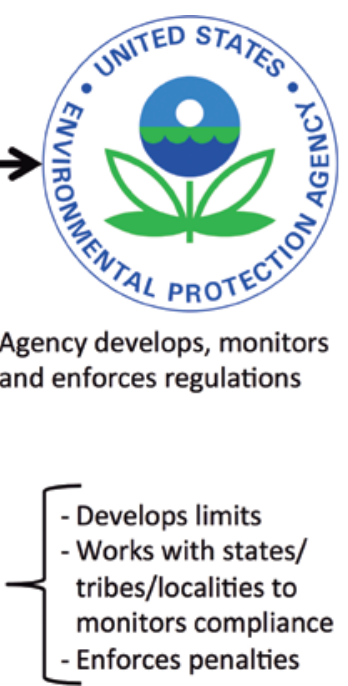

on the one before it, so the content of one document must be approved before the next one can be completed.

The environmental policy review process in the US has many exemplary features. The US National Ambient Air Quality Standards process includes accessible reports, open feedback, and leveraging of the scientific community. It is also reviewed often and revised as needed. The features of this process have evolved over time and stem from the structure of underlying authority.

\section{The Role of the Academic Community}

The US process includes key roles for the public, private, and academic sectors. Academics are important to the process for four major products: peerreviewed scientific production, wellprepared scientists, well-prepared policy makers, and an informed public. Academics help contribute to these system-level products in four concrete ways: 1) preparing supporting reports, 2) providing feedback and review, 3) research to support post policy permitting/licensing, and 4) policy development. As a physical scientist myself, I will not discuss policy development further, but I will point out that policy makers cannot design good policies without knowledge of the processes involved.

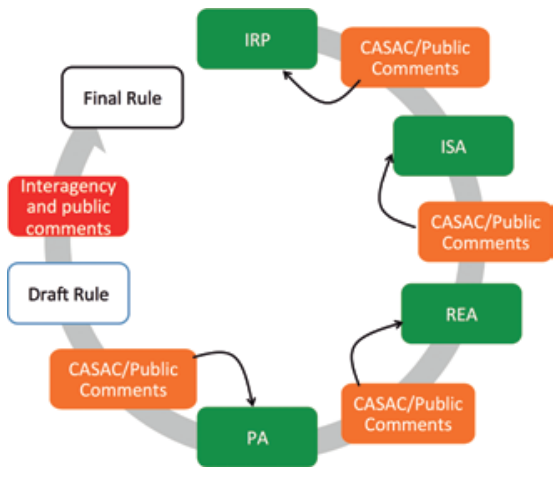

Figure 2. Rulemaking process used to set the new EPA ozone National Ambient Air Quality Standard (acronyms defined in text). Source:

\footnotetext{
2 http://www3.epa.gov/ttn/naaqs/standards/ozone/s_ o3_index.html

3 http://www2.epa.gov/dockets/commenting-epadockets
}

Own work. 


\section{Supporting REPORTS}

The reports developed in US environmental policy making (ISA, REA, and PA; green in Figure 2) rely heavily on the peer-reviewed science and scientists produced by the academic institutions. Peer review processes are developed, maintained, and operated by academia along with private researchers and government researchers. Similarly, the content in the peer-reviewed literature is generated by the same groups. Peer-reviewed scientific production is used in each report, and is the primary content of the ISA along with EPA synthesis. The EPA scientific synthesis would not be possible without the academic community. First, the EPA scientists themselves have MSc., MSEE, or Ph.D. degrees in science and engineering disciplines, and many coauthors on the ISA, for example, are from academia. So members of the academic community write science and produce scientists that contribute to the development of policy.

\section{Feedback and Review}

Feedback and review of work at the EPA is fundamental to the success of the agency and academia plays three related roles:

1. Direct Feedback: Academics ensure that science is appropriately interpreted and that simple mistakes do not propagate through the system. This feedback occurs in several forms. Scientists are engaged during the writing of the report, but they are also able to enter feedback during the "public comment" period. In fact, scientists (academicians and private) are often paid to formulate responses to each report and draft policy.

2. Formal Review: Academia provides formal review via Clean Air Scientific Advisory Committee (CASAC). Of the seven chartered members of CASAC, four are from
Universities (including the chair), two are from private research institutes, and one is from a non-profit regional partnership of air quality agencies (NESCAUM). In this role, all members take on the responsibility of direct oversight of supporting reports. CASAC members have a responsibility to remain impartial and must disclose financial reports and be trained in ethics to ensure impartiality.

3. The academic community educates the public to help provide a relevant "public comment," which is most useful to the public and the EPA when commenters understand the issues they are responding to. While it is unreasonable to expect every member of the public to be a scientist, it is our responsibility to impart practical scientific knowledge to all students that come through primary and secondary education.

\section{EXAMPLES FROM THE FIELD}

My career has included work on supporting reports, educating scientists and the broader public, as well as reviewing permits. In this article, I discuss two of those experiences in the order they fall within the process: 1) Coauthoring the ISA and 2) Reviewing Permitted Facilities.

\section{CoAuthoring THE ISA}

In 2012, I was fortunate enough to be included as a coauthor on the Integrated Science Assessment. From 2008 to 2012, I worked on air quality science that was particularly relevant to the 2012 ISA. At the same time, I worked at the EPA as a researcher through the Oak Ridge Institute for Science and Education (ORISE), where I was invited to participate in writing and developing content for the ISA. The experience gave me a great appreciation for

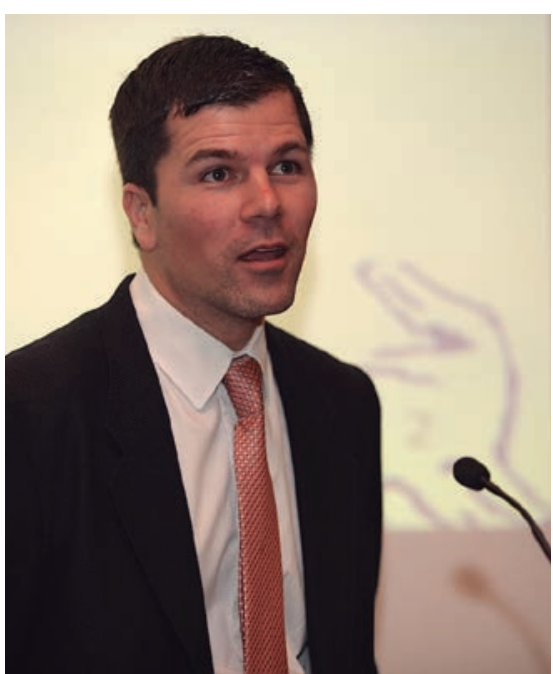

Barron Henderson. Fuente: Archivo Particular, Universidad de los Andes

the larger processes of policy development starting with drafting the ISA, receiving CASAC and public feedback, and revising the final version.

Working on the ISA is a daunting task because it is so expansive. Although the ISA only includes new science since 2006, it considered 4074 citable documents, it was revised four times, and the final report had 1251 pages with 2276 cited documents. ${ }^{4}$

My specific role focused on Chapter 3, Section 4 and was extremely detailed (U.S. EPA, 2013). We studied "background ozone" or ozone that is produced outside the US. Specifically, the goal was to understand how different reports came to different conclusions about the importance of background ozone to the attainability of the proposed standard (at the time consideration was from $60 \mathrm{ppb}$ to $75 \mathrm{ppb}$ ). We contacted the authors of two studies and requested their data, which they provided. (Note that public access to the data was a key element.) We then analyzed both studies in hundreds of different ways and published a memo to the docket (Henderson et al, 2012). We found that differences in chemistry, and resolution led to differences in

\footnotetext{
4 http://hero.epa.gov/index.cfm/project/page/project_id/1628
} 
results even though both studies had some common strengths and weaknesses.

Our first and second drafts of the ISA section detailed the differences between studies, but that was not enough. The CASAC and public comments pushed us to go further. It was critical that the underlying uncertainties be clearly addressed. This was perceived as important due to a combination of the state-of-the-science, the potential regulatory implications, and public feedback. At public meetings, the importance of background ozone, and stratospheric intrusions in particular, was emphasized by consultants acting on behalf of states and companies. Background ozone was identified as a potential problem for western states if the standard was set too low. Background ozone could cause exceedences that would be hard to conclusively identify as "exceptional" events.

The degree of detail pursued in our section demonstrates the value of the ISA process. First, we brought together the latest and best research on the topic and dissected it. Second, we were pushed to characterize the implications for policy makers. Third, the feedback from consultants acting on behalf of businesses and feedback from the CASAC pushed the report to support decision makers. This experience helped me to more fully understand the importance of formal review and frequent reconsideration.

\section{Reviewing Permitted EMISSIONS}

As a consultant and as a faculty member, I have often been asked to review permits or permit related material. The most interesting review of a facility that I ever performed was completely unnecessary from a regulatory standpoint, yet important in terms of stakeholder engagement. Here I will discuss why the review happened, what was reviewed, and conclude with why the review was a good idea.
The team at the University of Florida was contacted by the Solid Waste Authority (SWA) of Palm Beach County, FL to review one of their Renewable Energy Facilities (REF). SWA had already obtained their permit and was clearly operating within their permit. The facility was simply making changes to their plan, which triggered public awareness and concern. The facility agreed to an external review to address public concerns.

Our review covered issues including litter, noise, odor, and emissions of health pollutants and greenhouse gases. We generated a 320-page report and gave a presentation for the county board and the public (Schert et al., 2014). Each issue was addressed within the limits of available data, the state-ofthe-science, and our time constraints. The findings of our report were not distressing.

If the company was within its permit and our results did not reveal anything distressing, why was this work still a good use of time? It was a good idea because SWA was operating as a good citizen of their community. The regulatory process does not guarantee that the public concerns have been addressed, and sometimes revealing the impacts (or lack thereof) helps to alleviate the concerns of local stakeholders.

\section{SUMMARY}

The US EPA environmental licensing process has many opportunities for scientists, engineers and the more general public to engage. Our job as scientists and engineers doesn't begin with a regulation, and it doesn't end with a facility design or operation. As illustrated by my experiences with the US NAAQS and facility review, we are involved before the regulation is written, and we retain an important role even have after facilities are designed. That is just as true in Colombia as it is in the US. Academics are called to engage in the regulatory process because we have the tools and expertise to protect humans, to help protect the environment, and to change the world a bit at a time in the process.

\section{REFERENCES}

Frequently Asked Questions and Answers for External Experts Interested in Serving on EPA Clean Air Scientific Advisory Committee (CASAC) Review Panels, n.d. http://yosemite.epa.gov/ sab/sabproduct.nsf/WebFiles/ FAQsCASACReviewPanels/\$File/ QsandAsCASACExtExp.pdf

Henderson, B., Possiel, N., Akhtar, F. \& Simon, H. (2012). Regional and Seasonal Analysis of North American Background Ozone Estimates from Two Studies (Memo No. EPAHQ-OAR-2012-0699). U.S. EPA, Research Triangle Park, NC.

HERO: Health and Environmental Research Online: http://hero.epa.gov/ index.cfm/project/page/project_ id/1628

Members of the Clean Air Scientific Advisory Committee, n.d. http://yosemite.epa.gov/sab/sabpeople.nsf/ WebExternalCommitteeRosters?O penView\&committee $=$ CASAC

Oak Ridge Institute for Science and Education, http://orise.orau.gov

Schert, J., Vinson, T., Li, S., Townsend, T., Henderson, B.H., Darnell, M., Roberts, S. \& Meeroff, D. (2014). Examination of Issues Surrounding Excess Capacity Utilization for Palm Beach Renewable Energy Facility \#2. Solid Waste Authority, Palm Beach County.

U. S. Environmental Protection Agency. Website. http://www3.epa.gov/

U. S. EPA. (2013). Integrated Science Assessment for Ozone and Related Photochemical Oxidants (No. EPA 600/R-10/076F). U.S. Environmental Protection Agency, Research Triangle Park, NC. 